\title{
FINAL FALSE START (ABOUT THE CATASTROPHIC REVOLUTION OF 1991)
}

Yuri V. LATOV, Dr. Sci. (Sociol.), Cand. Sci. (Econ.), Chief Researcher, Institute of Sociology of FCTAS RAS; Prof., Russian University of Economics. G.V. Plekhanov, Moscow, Russia (latov@mail.ru).

\begin{abstract}
There are two aspects in the events of 1991, each of which can be called both a negative "catastrophe" and a positive "revolution": this is the death of the "socialist experiment" and the collapse of the "imperial" USSR, the latter being a derivative of the former. For an objective understanding of the significance of these events, they must be considered in the context of long-term institutional socio-economic changes (first of all, the evolution from industrial to post-industrial society) and taking into account the modern theories of the sociology of revolutions. This approach leads to the conclusion that the main content of the events of 1991 is an objectively progressive "anti-nomenclature" (antipolitical) revolution that took place "from above" (and therefore very inconsistent). It put an end to the Soviet system, which claimed to present "real socialism", but in fact turned out to be the "second edition" of the so-called Asiatic mode of production, and therefore, despite many "mobilization" achievements, it reached a dead end. Since the ex-Soviet "nomenklatura" was able to largely maintain (and in some aspects even strengthen) its privileged position, this creates a public demand for a new cycle of revolutionary events.
\end{abstract}

Keywords: the death of the USSR - theory of socio-economic systems - "real socialism" • post-industrial society • "Asiatic mode of production" • political society • sociology of revolution

DOI: $10.31857 / S 013216250017621-6$

This article is a translation of: Латов Ю.В. Финал фальстарта (о катастрофической революции 1991 г.) // Sotsiologicheskie Issledovaniia. 2021. No 12: 67-77. DOI: 10.31857/ S013216250015525-0

Two aspects of the same ruin. There are two aspects to events of 1991, each of which could be determined as a negative "catastrophe" and a positive "revolution". The essence of both of these processes, despite the past 30 years, remains debatable. If liberals consistently welcome both the liquidation of the Soviet system and the collapse of the USSR, then their opponents have a more complex attitude to what was being destroyed 30 years ago. For some persons, the main tragedy is the death of the socialist "experiment", and the collapse of the USSR is only a continuity of it (this position is expressed by Marxists A.V. Buzgalin and A.I. Kolganov in this sense). For others ones, on the contrary, the main thing is the collapse of the USSR, and the rejection of socialism, as the antithesis to capitalist market economy, is naturally inevitable [Toshchenko, 2021; Simonyan, 2021].

The question of whether the disintegration of a large multiethnic state into smaller monoethnic countries is progressive or reactionary, from a scientific point of view, does not deserve discussion. If all other factors are working equal, a large state develops better than a small one: the internal market is wider, there are more opportunities for division of labor, political competition for choosing the best ways of development is harder, and opportunities for interaction between cultures are better. Therefore, if a multiethnic state develops successfully and internal intercultural differences are not great, then centripetal trends prevail over centrifugal ones. An example is modern Great Britain (England, Wales, Scotland and Northern Ireland), which, 
even after centuries of assimilation of non-Englishmen, does not differ much in polyethnicity (Englishmen are about 75\%) from the late USSR (Russians were 50\%).

However, a multiethnic country experiencing a crisis in front of maintaining strong interethnic differences is doomed to be "dragged into national blocks." This was the case in the 1990s not only of the USSR and Yugoslavia, but even the case of the more "calm" Czechoslovakia (and at the beginning of the twentieth century of Austria-Hungary and Turkey). If the dismantling of the Soviet system had caused a rapid economic recovery, as in China during the 1980s after Deng Xiaoping's reforms, then "pulling USSR apart" could have been prevented. But even now there are few prerequisites for such an economic rise. The bloody interethnic conflicts that began already in the last years of "perestroika" show that the rapprochement of nations of the USSR took only the first steps and therefore could not stand in "difficult times ${ }^{1 "}$.

The main theoretical question, on the solution of which, according to the logic of the formation analysis, an assay of the events of the early 1990s depends, is the definition of the essence of "real socialism". If it was a social system of a highest order, then the termination of the "experiment" deserves condemnation as it can be determined as a regression, even if it led to temporary successes (for the sake of the "chickadee in a hand" they abandoned the "crane in the sky"). And if "real socialism" was not higher, but lower than "real capitalism", then the rejection of the first one is progressive, even if it led to temporary failures (an analogy is the transition from the ancient system to feudalism after the fall of the Western Roman Empire in the fifth century).

The author wants to present a hypothesis explaining the meaning of the events of 1991 as a catastrophic, but still a progressive revolution. This hypothesis must be simultaneously a synthesis of the views expressed in the previous articles in the "Sociological Research" about the meaning of those events, and a polemic with thees ones.

The global "struggle between capitalism and socialism" as a post-industrial shift. First of all, the discussion of the events of 1991 in terms of a confrontation between "capitalism" and "socialism" does not seem quite correct, since the correspondence of these concepts to the realities of the modern era is under big question.

It is rule in the Marxist tradition to call the "capitalism" a social system, which bases on the exploitation of hired workers by the owners of the means of production. However, even if we do not consider the theoretical discussions about the validity of the original Marxian theory of exploitation, the opposition in modern conditions of the owners of the means of production to the owners of labor is questionable. It is enough to recall the theory of human capital, according to which the main resource is not external means of production, but "human qualities" inseparable from the personality (knowledge, skills, motivation, etc.), so that the owners of the main means of production are the employees themselves.

"Socialism" was determined as a social system where two classes (workers and collective farmers) act under the dominance of public property. However, it is difficult to find in the USSR exactly such a biclassicity and public property. Russian sociologists write exactly about the confrontation in Soviet society of "managers" and "subordinate" people [Tikhonova, 2021], which confirms the "dissident" concepts of "nomenclature" as the ruling class (for example, [Voslensky, 2005]). And what was called public property in the USSR is much more correct to call simply state property, since the people had little influence on making decisions on its management, and these decisions themselves did not always had base as objective interests of the people. As a result, even its modern defenders often call "socialism" not a progressive social system,

${ }^{1}$ In this regard, the regrets expressed by R.H. Simonyan about the missed opportunity to sign thr new Union treaty in 1989 [Simonyan, 2021: 68-70] seem to be legal fetishism: the "(not) correctness" of the design of agreements does not prevent them from being ignored in the new alignment of socio-political forces. The draft of the new union treaty, as can be clearly seen from R.H. Simonyan's "included observation", was rather significant as an attempt by the party elite of the national republics to intercept the initiative of non-party nationalists in the defense of "independence". And the interpretation of the root-of-the-leadership cadres as one of the main factors of the collapse of the USSR [Mironov, 2021] only confirms the illusory nature of the "Soviet people", which, it turns out, was held only by the Russian "elder brother". 
but a system of strong social policy ("social state"). And when they talk about the save of "socialism" in China (where social protection is still "not very" strong), then in fact they mean only strong centralized governance, monopolized by the Communist Party.

Since the discussion of the "transition from capitalism to socialism and back" is complicated by the vagueness of basic concepts, it is advisable to switch to the conceptual apparatus of the theory of post-industrial society formed in the second half of the twentieth century. Although it has Marxist roots [Latov, 2017], its formation and development can be rightfully regarded as a liberal "response" to the Marxist "challenge".

After all, the main content of the post-industrial shift is the transition from the dominance of the branches of the material sphere to the dominant role of the production of intangible goods (services). K. Marx argued a century and a half ago that industrial capitalism would be replaced by a new social system that would be "on the other side of material production" [Marx, 1962: 387]. The Marxists were also right in predicting objective tendencies to overcome the alienation of workers from labor, from management and from property. Indeed, if the industry of the XIX century required a " $\mathrm{cog}$ " worker capable of monotonous actions under the control of craftsmen and engineers, then from the second half of the twentieth century the demand for an employee capable of self-organization and self-control at his workplace has been growing rapidly.

At the same time, the Marxists were mistaken, hoping to overcome alienation by means of nationalization and involving all workers in a state administration (when "every cook must learn how to manage the state"). The history of the twentieth century has shown that the complexity of management is growing faster than the growth of the level of education. Therefore, the overwhelming majority of employees still cannot and does not want to be involved in the development, adoption and implementation of management decisions, even at the municipal level, not to mention the national ${ }^{2}$. In addition, it was only at the beginning of the XXI century that the tools of "electronic government" appeared, allowing citizens to speak regularly and practically without costs on issues of local and public administration. But even in the most developed countries, they are in no hurry to turn the possibility of permanent electronic surveys of citizens into a tool of direct democracy, justifiably fearing the dominance of unskilled opinions over qualified ones. Management remains a matter of professionals alienated from the controlled mass, which inevitably generates bureaucratization of state power.

Under the influence of criticism of the "failures of the state," researchers of postindustrialism tried to "purify" the Marxist idea of socio-economic progress from naive hopes for the omnipotence of state control. As a result, attention has shifted from the issues of changing ownership of the means of production to the issues of shifting power (management) under the influence of changes in production technologies.

This shift in attention of researchers is also due to the fact that the very understanding of property as a social relation (institution) in the second half of the twentieth century has changed significantly under the influence, first of all, of neo-institutionalist economists. The orthodox Marxist social science interpreted property relations in a quantized way, since in the XIX century, the practically unlimited owner of the means of production was indeed most often a specific private entrepreneur. This approach gave rise to a rigid opposition between private and public property, from which appeals to the "expropriation of expropriators" logically

${ }^{2}$ In this regard, the interpretation of the All-Union referendum in March 1991 proposed by J.T. Toschenko [Tosh 2021: 10] as evidence of the firm will of the peoples of the USSR to save its unity is easy to criticize. Yes, at this referendum, $76 \%$ of its participants considered it "necessary to save the Union of Soviet Socialist Republics as a renewed federation of equal sovereign republics." But only $80 \%$ of the entire electorate took part in the referendum, in the RSFSR the figures were even lower ( $71 \%$ supported with a $75 \%$ turnout, i.e. $53 \%$ of citizens voted for the save of the USSR). And the "firmness" of the will of the referendum participants is evidenced by the fact that when the Belovezhskaya Agreement on the termination of the USSR was concluded in December of the same year, it did not cause any protests. Is there much worth an opinion, which a citizen does not want actively to defend? 
came up. But since the middle of the twentieth century folowing a development of joint-stock business and various forms of macro-regulation, an understanding of property as a bundle of partial powers has been spreading. All this led to a qualitative change in the second half of the twentieth century. the point of view on the socialization of production. If a significant part of the powers (quality control of goods and competition rules, environmental restrictions, regulation of employee-employer relations ...) pass into the hands of the state and civil society institutions (trade unions, environmental organizations ...), then the question "whose property?" loses its former relevance, being replaced by the question "who will manage?" [Bell, 2004: 457]. The discussion of the exploitation of labor by capital is replaced by the discussion of the alienation of workers from labor, property and management. At the same time, the basic understanding of social progress, coming from Marxism was saved as a struggle for the transition "from the realm of necessity to the realm of freedom."

"Real Socialism" as the "second edition" of the political society. It is right to consider Soviet "real socialism" as an attempt to consciously develop society towards the post-industrial ideal as "communism". There are really no differences between them at the level of general concepts: it is no coincidence that Soviet fiction about the world of the future (Efremov's "Era of the Great Ring" or Strugatsky's "World of Half a Day") is regularly republished and read nowadays. The main question is how the presented ideal correlated with the living reality.

Defenders of "real socialism" often quote numerous memes characterizing the liberation of the individual in the USSR: "a person comes as a master," "a country of dreamers, a country of scientists," "a garden city," etc. But this is not the social reality itself, but its reflection in the minds of talented poets, which could be one-sided, crooked, or even simulacrum (to reflect a non-existent object). Finally, there is an alternative set of memes that characterize, on the contrary, the suppression of personality in Soviet society - "GULAG archipelago", "and if there are those which come to you, there will be those who will come to arrest you." And which set of memes is closer to reality? It is no coincidence that even at the highest level of the leadership of the USSR there was a feeling expressed by the aphorism of Yu. Andropov, that "we do not know the society in which we live."

The concept of "mutant socialism" proposed by A.V. Buzgalin (see his article in this issue) is successful in that it emphasizes the strong contradiction between what Soviet society wanted to be/seem to be and what this really was. At the same time, such a concept assumes that "socialism" was still somewhere in the beginning and only then mutated into something command-administrative, denying (but not completely) its socialist start.

The Bolsheviks knew about the danger of bureaucratic degeneration even before they came to power. Let us recall V.I. Lenin's textbook statement from "The State and the Revolution" (August 1917): "The workers, having won political power, will smash the old bureaucratic apparatus, ... replace it with a new one consisting of the same workers and employees, against the transformation of whom into bureaucrats measures will be taken immediately, analyzed in detail by K. Marx and F. Engels: 1) not only electability, but also changeability at any time; 2) wages are not higher than the wages of the worker; 3) the transition is immediate so that everyone performs the functions of control and supervision, so that everyone becomes "bureaucrats" for a while and therefore no one can become a "bureaucrat"' [Lenin, 1969: 86]. This caring ideal, reflecting first of all the absolute lack of real administrative experience at least at the municipal level, fundamentally could not withstand a collision with reality.

From the height of modern knowledge, it is clear that the method of overcoming alienation from power described by V.I. Lenin (in fact, the elimination of management as a special profession) will be possible hardly by the middle of the XXI century, requiring transparency in administrative decision-making and high qualifications of all citizens. In fact, even industrial self-government (through trade unions and factory committees, something similar will be implemented in Yugoslavia in the 1950s) lasted only a few months in 1917-1918 [Shubin, 2017: 207-235]. At higher levels of government, they did not even try to create an elected and regularly replaced administrative apparatus from workers in Soviet Russia. As a result, the philippics 
addressed to the Soviet bureaucracy, which leads the people, but does not obey him but the "authorities" have become a constant refrain of the entire Soviet history.

To denote what "real socialism" actually was, many different terms have been proposed, but their essence is similar: the result is an institutional system that is not higher than "real capitalism", but lower. Most often they recall the concept of the "Asian mode of production" proposed by K. Marx, or, in the version of the ex-Marxist K.-A. Wittfogel, "eastern despotism" [Wittfogel, 1957]. Since these geographically-oriented terms are not accurate and offensively contradict the established European identity of Russians, in the post-Soviet decades social scientists more often write, describing the Soviet regime, not about the Asian mode of production (like E.T. Gaidar [Gaidar, 2009: 189-194]), but about the political society [Semenov, 2008], power-property relations (L.S. Vasiliev, R.M. Nureyev, N.M. Pliskevich), the X-matrix (S.G. Kirdina). In all cases, this refers to the social system that existed for millennia in pre-colonial nonEuropean states, the basis of which is the monopoly of the state-class.

The "identification" of the Soviet society as the regeneration of a political society may seem like an ideologized slander aimed at discrediting the Soviet attempt to "storm the heavens". But if we compare "real socialism" with other examples of the "second edition" of archaic socio-economic systems (for example, with the "second edition of serfdom" in Eastern Europe of the XVI-XIX centuries or with plantation slavery in America of the XVIII-XIX centuries), then the Soviet experience will not be at all unique. Historical examples show that the regeneration of archaic socio-economic institutions can give a strong impetus to the development of a country, since these institutions are ineffective in the long term (on the scale of centuries), but in the medium term (on the scale of decades) they can be more effective than more advanced ones.

The Soviet version of the political society in the long term showed the inability to systematically carry out breakthrough technological innovations. Soviet scientists invented no worse than Western ones, but the industrial development of innovations often lagged behind due to the lack of incentives. There was no "competition as an opening procedure" (a successful definition of F. von Hayek), therefore the spontaneous mechanism of constant generation of competing innovations was replaced by "manual control".

At the same time, this social system was superior to Western countries in the ability to concentrate resources in clearly defined areas. Therefore, the Soviet regime has many clear successes in the mobilization development associated with "big projects": industrialization, the Victory in the Great Patriotic War, the Atomic project, the development of virgin lands, the Space project. These were, perhaps, Pyrrhic, but still undoubted victories, some of universal significance. When in the USSR in the 1960s the primary industrialization basically ended, the time of victorious "big projects" ended.

Under conditions of a "normal" socio-economic development, when the political elite has no clear goals for which it is necessary to mobilize a sociaty, the political society loses to the market one, this happened in the 1970s and 1980s. The "finishing of the game" could have ended, depending on subjective circumstances, not in 1991, but a year earlier or a decade later, this did not change the overall outcome of institutional competition on the "global chessboard".

"Real socialism" as a post-industrial false start. If the Soviet "experiment" ended in failure in 1991, does this mean that it was stillborn and erroneous from the very beginning?

It is right to consider "Real socialism" as a kind of false start as the movement of society in the right (post-industrial) direction, but undertaken before sufficient objective prerequisites were formed for this, and therefore doomed to "return to the start". One can fully agree with A.V. Buzgalin and A.I. Kolganov that the party founded by V.I. Lenin announced the beginning of the transition to a new social system in a country that has not yet "overcame" the previous social system. And then V.I. Lenin's ability to solve tactical tasks perfectly led to a strategic failure: the Communist Party won in a country where it is objectively too early to build communism. After all, Karl Marx wrote half a century before this Pyrrhic victory that "the working class will not have to implement any ideals, but only give space to the elements of a new society that have already developed in the bowels of the old collapsing bourgeois society" 
[Marx, 1960: 347]. There were in the Soviet Russia in the 1920s really ideals of socialists in the absence of not only "elements of a new society", but even a normal working class.

In this situation of a sharp gap between the declared ideas of the Socialist revolution and the real need to govern a "medium-weak" country, it was possible to take, first of all, the idea of centralized management of society in the name of socially useful goals from the socialist ideal for a real implementation. It was taken, coarsened to state administration in the name of those goals that the ruling elite considers socially useful. And this is a political society, where "the state is stronger than society."

The Soviet false start is not the only example in history when objectively premature realization of progressive intentions led to a dead end. An example for comparison is the Hussite movement in the Czech Republic in the first half of the XV century like a false start of the Reformation. As you know, many ideas of the Reformation related to the democratization of the church were expressed by Jan Huss and his followers a century before Martin Luther, who called himself as "Hussite". The Czech pre-Reformation had to end quickly, just like hundreds of other popular uprisings. However, the role of a crucial subjective factor (like V.I. Lenin in Russia) in the Czech Republic was played by the great commander Jan Zizka, thanks to whom the Hussites defeated enemies for 15 years and even began "exporting the revolution" to neighboring countries. However, the time did not come yet for the formation of "Protestant ethics as the spirit of capitalism". As a result, the victorious armies of the Hussites began to degenerate into communities of professional robber warriors. The Czech "experiment" ended about 70 years later in almost the same way as the Soviet one: first, the radical Hussites were killed by the moderates, then the moderate Hussites went to restore the old order on the terms of preserving part of the privileges.

Although a general theory of false-start phenomena in social development has yet to be created, in the first approximation it can be noted that they are characterized by a contradictory combination of progress and regression. The bold search for new "rules of the game" creates favorable conditions for the emergence of "enclaves of the future" (new ideas and values, new organizational structures), surrounded, however, by much more archaic elements. Since the Soviet political system considered itself to be the realization of Marxist ideas about socialism, the propagandized social ideal really remained socialist, dissonant with the real rules of life. The development of the USSR economy objectively stimulated the development of elements of creative work and post-monetary motivation to work. But until the very end of the Soviet society post-industrial "enclaves", territorial (including, for example, centers of high-tech technologies such as Arzamas-16) and institutional, were inconsistently combined with an incompleteness of even industrial modernization on a national scale.

This unity-and-struggle of "socialism" and "politarism" led to the fact that over time, as the stalemate of the path of the Soviet development increased, regressive elements prevailed over progressive ones. It is natural that it was the Soviet intelligentsia as the main social group in which the alienation from labor was overcome, which in the last years of the USSR's existence acted as the main actor, which required radical market changes. Overcoming alienation from labor, property and management among Soviet people, limited in the choice of work, deprived of property and self-government opportunities, ran into a limit. For further movement into a post-industrial society, it was necessary to return to private property and the market, in order to then dialectically rise above them, but not mechanically destroy them.

A lot of critics of Gorbachev and Yeltsin's reforms/Gaidar admits that the "socialist experiment" had to be completed, but they accuse the reformers for too "rude" actions. However, when critics of the events of 1991 point to the missed opportunity for the smooth dismantling of "real socialism" (i.e., the transition from an administrative-command economy to a market economy), they forget that such attempts have actually been more than once, but ended in failure. They were undertaken in the USSR (the NEP of the 1920s, the Kosygin reform of the second half of the 1960s), and in other countries of the "socialist camp" (for example, in Hungary after 1956), and the Yugoslav version of "real socialism" was initially based on "self-financing". But while maintaining centralized management of the "nomenclature" alienated from the 
population, all attempts to expand the independence of enterprises and the initiatives of individual employees inevitably "went down on the brakes."

So, the transition from the command and administrative system to a market economy turned out to be possible only through the "anti-nomenclature" revolution - through qualitative changes in the political and economic systems, assuming the return of the dominance of the basic institutions of "capitalism" (market, private property and competition). Such a revolution required a radical personal renewal of the highest elite, a radical change in ideology (rejection of the Soviet version of communism as the official ideology) and, most importantly, mass privatization of state property.

1991 and other years: "revolution" or "trauma"? Since the most important qualitative changes took place on the eve and after the "abolition" of the USSR in the economic sphere, for liberal economists who justified them, the revolutionary nature of the events of 1991 was and remains self-evident [Gaidar, 2009: 256; Popov, 2016: 435; etc.]. There are other Russian social scientists which call the death of the Soviet system a revolution (for example, [Letnyakov, 2018]). However, a different approach prevailed among Russian sociologists, which coincided with V.V. Putin's thesis expressed in 2005 ("the collapse of the USSR is the largest geopolitical catastrophe of the century"), but this idea was formulated much earlier.

At the origins of the "catastrophist" scientific perception of the events of the early 1990 s is the "Modern Russian Society" published shortly after the end of the Yeltsin period by T.I. Zaslavskaya. The intellectual leader of Russian sociology, arguing with the concept of the Great Russian Revolution of 1991-1993 put forward by liberal economists, categorically rejected it on several grounds: there was no radical change of the elite in the country, mass social movements did not receive much development, "majority problems" were not solved during the transformation, and the scale of political violence was very limited [Zaslavskaya, 2004]. However, from the point of view of the sociology of revolution (see the review in [Latov, 2021]), such a justification raises strong doubts.

There is the post-Soviet social science, which takes the understanding of the revolution, given back in the 1960 s by S. Huntington, remains: "Revolution is a fast, fundamental and violent [emphasis added.- Approx. Y.L.] change of dominant values and myths of society, its political institutions, social structure, leadership, government activities and politics produced by the internal forces of society" [Huntington, 2004: 269]). But there is in modern foreign sociology of revolutions T. Skochpol's definition given in the 1970s as preferred with other accents: "Social revolutions are rapid, fundamental transformations of the social state and class structures; and they are accompanied and partially carried out through class uprisings from below" [Skochpol, 2017: 25].

As can be seen, Skochpol still has an understanding of the revolution as rapid and fundamental changes, but the indication of their necessarily violent nature has gone. After the "color" revolutions, which unfolded in the 1980s, where armed uprisings were replaced by mass protests by unarmed citizens, the American sociologist D. Goldstone gave a new, even "more modern definition of revolution: this is an attempt to transform political institutions and provide a new justification for political power in society, accompanied by formal or informal mobilization of the masses and such non-institutionalized actions that undermine the existing power" [Goldstone, 2006: 61]. Thus, when defining a revolution, the sign of the presence of violent actions has been replaced by the anti-government mobilization of the protesting masses. The events of 1991 perfectly fit the definitions of Skochpol and Goldstone, and their interpretation as revolutions has long been expressed in the Western social science [Goldstone, 2001].

But Russian sociologists have chosen a different way. Rejecting the concept of "revolution", T.I. Zaslavskaya argued that "in the 1990s, not a revolution took place in Russia, but an evolution" - "a spontaneous transformation of society began, which led to a sharp weakening of the state and the growing criminalization of the society" ([Zaslavskaya, 2007: 186]). As main distinguishing features of this transformation, she identified the following signs: "1) the gradual and relatively peaceful nature of the course; 2 ) the focus on changing not individual private parties, 
but the essential features that determine the societal type of society; 3 ) the fundamental dependence of the course and results of the process on the activities and behavior of ... mass social groups; 4) weak controllability and predictability of the process, the important role of natural factors of development, the non-resolution of its results; 5 ) the inevitability of ... anomie caused by the advanced decomposition of old public institutions compared with the creation of new ones" [Zaslavskaya, 2007: 187]. It is not difficult to notice that the signs of "social transformation" coincide with the characteristics of a peaceful socio-political revolution, as it was described not only in the Western sociology of revolution, but even in Soviet social science.

The path chosen by the leaders of Russian sociology to reject the perception of the post-Marxist (represented by T. Skochpol and D. Goldstone) sociology of the revolution led to significant difficulties. Without referring to the concept of revolutionary processes, Russian scientists are forced to limit themselves to labeling the events of the early 1990s as traumatic [Toshchenko, 2020], avoiding analyzing whether we are talking about a "disease" of a degrading society or a "generic" trauma accompanying the birth of any new social order.

Sour fruits of an unfinished revolution. At the same time, there are objective reasons for the "catastrophist" perception of the events of the early 1990s, since disillusionment with the fruits of post-Soviet transformations became commonplace almost immediately after they began. It is shared even by consistent liberals: "having chosen the right path, we failed not only to follow it more or less successfully, but, on the whole, we chose the worst - of all possible way out of socialism" [Popov, 2016: 774]. Therefore, it is legitimate to combine the opinions of those who consider the events of 1991 a catastrophe and those who call them a revolution: they were a catastrophic revolution. It has fulfilled its main task, replacing institutions of power-property with private property institutions, but at the lowest level and with maximum socio-economic costs.

The main failure of the "anti-nomenclature" revolution was already visible in 1992, so the events of 1993 were largely a protest not against the 1991 revolution, but against its incompleteness. Indeed, on the one hand, there has been a qualitative change in the "rules of the game": the directive planned economy has been replaced by a market economy, state property with a private one. However, on the other hand, the dominant social group has changed little: it was period of the 1990s, as ex-Soviet "managers" formed the backbone of the new business class; to a significant extent, the dominance (formal and informal) of the powerful over property owners has been saved, and since the 2000s the dominance (formal and informal) of the powerful over property owners has begun to take power again, which means a partial restoration of power-property (see, for example, [Pliskevich, 2008]). All this forms the basis of modern protest sentiments, directed, as 30 years ago, primarily against "bureaucrats".

Such incompleteness of even great revolutions is quite common. As well konown, the Great French Revolution of 1789 was the beginning of a long series of revolutions of 1830 1848-1871, so the creation of "normal capitalism" ended in France more than 80 years later. There is hardly any doubt that Russia has not exhausted the "limit on revolutions" either. At the same time, the institutions created by the revolution of 1991 (democracy, market, private property) have already been legitimized by the majority of Russians, so that "return to the USSR" is impossible. Therefore, it is legitimate to consider the events of the early 1990 s as the beginning of a long nonlinear revolutionary process with inevitable "ebbs" and "flows".

\section{REFERENCES}

Bell D. (2004) The coming of post-industrial society: A venture of social forecasting. Moscow: Academia. (In Russ.)

Gaidar E.T. (2009) Power and Property: Troubles and Institutions. State and evolution. St. Petersburg: Norma. (In Russ.)

Goldstone J. (2001) Theories of revolution, revolution 1989-1991. and the trajectory of development of «new» Russia. Voprosy ekonomiki [Problems of Economics]. No. 1: 117-123. (In Russ.) 
Goldstoun D. (2006) Towards a Fourth Generation of Revolutionary Theory. Logos. Vol. 56. No. 5: 58-103. (In Russ.)

Hantington S. (2004) Political order in Changing Societies. Moscow: Progress-Traditsiya. (In Russ.)

Latov Yu.V. (2017) What is on the other side of material production? Marxist roots and institutional branches of postindustrial theories. Istoriko-ekonomicheskiye issledovaniya [Historical and Economic Research]. Vol. 18. No. 1: 7-29. (In Russ.)

Latov Yu.V. (2021) From «Revolution» to "Transformations» and "Changes»? Development of Discourses of Analysis Qualitative Social Change. Sociologicheskaja nauka I social'naja praktika [Sociological Science and Social Practice]. Vol. 9. No. 1: 7-22. (In Russ.)

Lenin V.I. (1969) State and revolution. In: Lenin V.I. Full collection. 2nd ed. Vol. 33. Moscow: Polit. lit-ra. (In Russ.)

Letnyakov D.E. (2018) Anti-Communist Revolution of 1991: Towards a Demarginalization of the Term. Politicheskaya konceptologiya: zhurnal metadisciplinarnyh issledovaniy [The Political Conceptology: Journal of Metadisciplinary Research]. No. 4: 32-47. (In Russ.)

Marx K., Engels F. (1960) The Civil War in France. In: Marx K., Engels F. Collected Works. $2^{\text {nd }}$ ed. Vol. 17. Moscow: Politizdat. (In Russ.)

Mironov B.N. (2021) The formation of national elites as a factor in the disintegration of the USSR. Sotsiologicheskie issledovaniya [Sociological Studies]. No. 8: 33-48. (In Russ.)

Nureev R.M., Latov Yu.V. (2016) Economic history of Russia (experience of institutional analysis). $2^{\text {nd }}$ ed. Moscow: KNORUS. (In Russ.)

Pliskevich N.M. (2008) The «power-property» system in modern Russia. Voprosy ekonomiki [Problems of Economics]. No. 5: 119-126. (In Russ.)

Popov G. Kh. (2016) Frontiers of Gabriel Popov. Moscow: «Economicheskaya gazeta» (In Russ.).

Semyonov Y.I. (2008) Polytarian ("Asian») mode of production: essence and place in the history of mankind and Russia. Moscow: Magic Key. (In Russ.)

Shubin A.V. (2017) Start of the Country of Soviets. The revolution. October 1917 - March 1918. St. Petersburg: Piter. (In Russ.)

Simonyan R. Kh. (2021) How it was possible to preserve the Soviet Union (Baltic perspective). Sotsiologicheskie issledovaniya [Sociological Studies]. No. 8: 62-71. (In Russ.)

Skochpol T. (2017) States and Social Revolutions: A Comparative Analysis of France, Russia and China. Moscow: In-t Gaydara. (In Russ.)

Tikhonova N.E. (2021) Transformations of the social structure of Russian society: late 1980s - late 2010s. Sotsiologicheskie issledovaniya [Sociological Studies]. No. 8: 22-32. (In Russ.)

Toshchenko Zh.T. (2021) Was the geopolitical catastrophe of the USSR man-made? Sotsiologicheskie issledovaniya [Sociological Studies]. No. 8: 3-13. (In Russ.)

Toshchenko Zh.T. (2020) Society of Trauma: Between Evolution and Revolution (An Experience of Theoretical and Empirical Analysis). Moscow: Ves' Mir. (In Russ.)

Voslensky M.S. (2005) Nomenclature. Moscow: Zakharov. (In Russ.)

Wittfogel K.-A. (1957) Oriental Despotism. A Comparative Study of Total Power. New Haven: Yale University Press.

Zaslavskaya T.I. (2007) Favorites. T. 2. Transformational process in Russia: in search of a new methodology. Moscow: ZAO «Izd-vo «Ekonomika». (In Russ.)

Zaslavskaya T.I. (2004) Contemporary Russian Society. Social Mechanism of Transformation. Moscow: Delo. (In Russ.) 